Donald D. Tong, The Heart of Economic Reform: China's Banking Reform and State Enterprise Restructuring, Ashgate, 2002.

\title{
Françoise Lemoine
}

\section{(2) OpenEdition}

\section{Journals}

Édition électronique

URL : http://journals.openedition.org/chinaperspectives/363

DOI : $10.4000 /$ chinaperspectives.363

ISSN : 1996-4617

Éditeur

Centre d'étude français sur la Chine contemporaine

Édition imprimée

Date de publication : 1 juin 2003

ISSN : 2070-3449

Référence électronique

Françoise Lemoine, «Donald D. Tong, The Heart of Economic Reform: China's Banking Reform and State Enterprise Restructuring, Ashgate, 2002. », China Perspectives [En ligne], 47 | May-june 2003, mis en ligne le 10 novembre 2006, consulté le 24 septembre 2020. URL : http://journals.openedition.org/ chinaperspectives/363; DOI : https://doi.org/10.4000/chinaperspectives.363

Ce document a été généré automatiquement le 24 septembre 2020

(c) All rights reserved 


\title{
Donald D. Tong, The Heart of Economic Reform: China's Banking Reform and State Enterprise Restructuring, Ashgate, 2002.
}

\author{
Françoise Lemoine
}

\section{NOTE DE L'ÉDITEUR}

Translated from the French original by Jonathan Hall

1 This book's argument is well summed up in its title, namely that the restructuring of the banking system is inseparably linked with that of the state enterprises, and that both are necessary to carry out the reforms in China. This is because the enormous sums representing Chinese family savings are mostly deposited in the state-owned banks, but the latter fulfil their intermediary function very inefficiently, by allocating the major part of their credits to the low yield state enterprises rather than to the other more dynamic and profitable ones. There is an imperative to give large-scale support to the state enterprises, since these function as a social security net for much of the population. So the priority should be to set up a social security system outside the enterprises, in order to carry out reforms to both the banking system and the state enterprises simultaneously.

2 This argument is not original, but it is correct and well argued. The book has undeniably positive qualities, being extremely clear and instructive. Its different chapters (Development of the financial system, Financial institutions and investment, Sources of finance and investment, Channels for transforming savings into investment, Investment efficiency and growth, etc.) cover each question and provide the relevant figures. Chapter 10, in particular, gives us a complete and precise summation of the social functions of the state enterprises and their costs. 
In most of the chapters the analysis ends a bit early. The final year referred to is usually 1996, both for the analysis and for the numerical data. So more recent developments are not taken into account, and some of the chapters provide information which seems outdated. Major recent developments are only taken up in a concluding chapter.

4 Moreover some of the assertions are debatable. While it may be true that employees are better treated than creditors when the state enterprises fail, this does not justify the view that it is the size of the redundancy payments that prevents the restructuring of the state enterprises (p. 160). Other analyses are a little summary and superficial. He interprets the shortfall between the number of direct overseas investment contracts drawn up and the number actually carried through to completion, as being due to a lack of investor confidence and/or obstacles to capital inflow (p. 46); but this is not very convincing, given the large overall volume of such investments and the impenetrability of Chinese statistics in this area. The description of the stock markets omits to mention that most of the market capitalisation is in the hands of institutional investors, and that these shares are not available on the open market. The idea that the development of the stock markets is a means of improving the allocation of resources because "the capital markets provide an efficient means of enabling shareholder control over enterprise managements by avoiding cosy relationships between the banks and the enterprises" (p. 179) seems at best a bit premature in the case of China. At another point, his analysis of the slowdown in growth rates in the latter part of the 1990s links it to a fall in demand, which is itself a consequence of growing unemployment and job insecurity (p. 181). This is an explanation that is often put forward. But in the context of this work devoted to the dysfunctional financial system, it would have been useful to mention another possibility advanced by some economists, namely that the original cause of the slow growth rate is not to be found on the demand side but rather on the credit supply side, owing to the reluctance of the banks to lend to private enterprises. According to this argument there is an unmet demand for credit in the private sector, due to the dysfunctional nature of the banking system and the cap on interest rates.

5 To sum up, then: the very qualities of this work tend to bring their defects with them. It is clear and simple, but sometimes errs a little too much in that direction. 